BARTOSZ ADAMCZEWSKI, WARSZAWA

\title{
KSIĘGA AMOSA I LISTY PAWŁOWE W DZIEJACH APOSTOLSKICH
}

Księga Amosa explicite cytowana jest w Nowym Testamencie tylko dwa razy. Oba cytowania znajdują się w księdze Dziejów Apostolskich. ${ }^{1}$ Co więcej, oba cytaty - i tylko te dwa cytaty - wprowadzone zostały w Dziejach Apostolskich za pomocą tej samej, zapożyczonej z listów Pawłowych formuły: ,jak napisano” (kathōs gegraptai: Dz 7,42; 15,16; por. także Łk 2,23). ${ }^{2}$

Forma tych cytatów w Łukaszowym dziele jest jednak nietypowa, gdyż nie pokrywa się ona z wersją tekstualną, znaną z Septuaginty, na której generalnie opierał się św. Łukasz. Czy zatem Łukasz korzystał w tym przypadku z jakiejś innej greckiej wersji Księgi Amosa, czy też może z jakichś powodów świadomie zmodyfikował oba cytowane przez siebie teksty? Może zaś, skoro oba cytaty wykorzystane zostały łącznie także w Dokumencie Damasceńskim (CD 7,14-16), ${ }^{3}$ opierał się na tym właśnie hebrajskim dokumencie?

Odpowiedź możliwa jest na drodze analizy funkcji argumentacyjnej i intertekstualnej, jaką oba cytaty z Księgi Amosa pełnią w Łukaszowym dziele. Analiza ta w dość nieoczekiwany sposób wiąże się z szeroko dyskutowanym ostatnio zagadnieniem użycia w Dziejach Apostolskich listów św. Pawła.

1 Przywołane w Księdze Apokalipsy wyrażenie kyrios ho theos ho pantokratōr (Ap 4,8 itd.) nie jest specyficzne dla Księgi Amosa (Am 3,13 LXX itd.), gdyż występuje także w Oz 12,6; Na 3,5; Za 10,3 LXX. Trudno stwierdzić zatem, czy jest to cytat akurat z Księgi Amosa.

2 Por. P. A. P a u $1 \mathrm{o}$, Le problème ecclésial des Actes à la lumière de deux prophéties d'Amos, Recherches, ns 3, Montréal-Paris 1985, s. 47.

3 Por. tamże, s. 48. 


\section{Cytat z Am 5,25-27 LXX w Dz 7,42-43}

Pierwszym z cytatów z Księgi Amosa w Dziejach Apostolskich jest przywołany w Dz 7,42-43 grecki tekst Am 5,25-27. Został on wykorzystany przez św. Łukasza we fragmencie mowy Szczepana, ukazującym bałwochwalstwo izraelskich „ojców” na pustyni (Dz 7,39-43).

Forma greckiego cytatu z Am 5,25-27 w Dz 7,42-43 generalnie odpowiada wersji Septuaginty. Widoczne są jednak także dość istotne różnice w stosunku do tej, zwykle używanej przez św. Łukasza, wersji tekstu Starego Testamentu.

Pierwsza z tych różnic dotyczy szyku wyrazów w pierwszym, pytającym zdaniu cytatu. O ile w Am 5,25 LXX, a także w odpowiadającym mu tekście hebrajskim, szyk ten podkreśla lokalizację braku kultu Jahwe na pustyni (en tē erēmō tessarakonta etēe - ,na pustyni czterdzieści lat"), o tyle w Dz 7,42 szyk ten podkreśla długi, czterdziestoletni okres trwania tego bałwochwalstwa (etē tesserakonta en tē erēmō„lat czterdzieści na pustyni”). Wskazanie na długość czasu, bardziej niż na lokalizację, może być echem wcześniejszych Łukaszowych wzmianek dotyczących czterdziestoletnich okresów w życiu Mojżesza (Dz 7,23.30.36). Może ono jednak także wyraźniej wskazywać na długotrwałość bałwochwalstwa Izraelitów, które w Łukaszowym tekście jest nie tylko jednorazowym epizodem z okresu wędrówki na pustyni (por. Wj 32,1-24; Dz 7,40-41), ale niejako stałą postawą Izraelitów, którą przepowiadał już prorok Amos (Dz 7,42-43; por. Am 5,25-27). ${ }^{4}$ Ponieważ podobna myśl wyrażona została także w konkluzji mowy Szczepana (Dz 7,51-53), należy uznać, że mamy tu do czynienia ze świadomą przeróbką tekstu Septuaginty, a nie z wykorzystaniem przez św. Łukasza innej wersji greckiego tekstu Księgi Amosa.

Kolejna różnica dotyczy obecności w Dz 7,43 czasownika proskynein („oddawać cześć”), którego nie ma w Am 5,26 LXX ani w odpowiadającym mu tekście hebrajskim, ${ }^{5}$ a który przejęty został

4 Por. tamże, s. 66.

5 Por. tamże, s. 61, 63. 
z Wj 32,8 LXX, ${ }^{6}$ względnie z Pwt 4,19 LXX. ${ }^{7}$ Łukaszowa forma cytatu podkreśla w ten sposób fakt, że Izraelici uczynili na pustyni wyobrażenia pogańskich bogów nie tyle ogólnie „dla siebie”, jak to przedstawia zarówno hebrajski, jak i grecki tekst Am 5,26, ale w konkretnym celu, a mianowicie po to, „aby cześć im oddawać” (Dz 7,43). ${ }^{8}$ Ten drobny z pozoru dodatek, wraz z wcześniejszą modyfikacją szyku wyrazów, zasadniczo zmienia więc obraz kultu Izraelitów na pustyni. W miejsce opisanego w Wj-Kpł-Lb kultu Jahwe w tymczasowym Przybytku, w tekście Dz 7,42-43 pojawia się obraz całego czterdziestoletniego okresu wędrówki przez pustynię, jako czasu nieustannego, świadomego kultu wyobrażeń pogańskich bóstw. ${ }^{9}$ Opisany dalej przez św. Łukasza Namiot Świadectwa, uczyniony przez Mojżesza, po prostu „był” u Izraelitów (Dz 7,44), a potem został przez nich wniesiony do ziemi pogan $(\mathrm{Dz} 7,45)$. W istocie nie pełnił on jednak funkcji miejsca kultu Najwyższego, ${ }^{10}$ podobnie jak nie był nim „dom”, zbudowany później przez Salomona (Dz 7,47-50). Modyfikacja cytatu z Am 5,26 znów nie jest więc wynikiem zastosowania w Dz 7,43 innej wersji greckiego tekstu, ale służy potwierdzeniu myśli, wyrażonej przez św. Łukasza także w szerszym kontekście, a mianowicie świadomego pomijania i deprecjacji całego kultu Izraela, opartego na składaniu ofiar w Przybytku.

6 Por. tamże, s. 66.

7 Por. R. K e s s le r, Wüstenzeit und Sternenkult: Eine Übersetzungstheoretische Studie zu Amos 5,25-27 im masoretischen Text, in der Damaskusschrift, der Septuaginta und Apg 7,42f, Texte \& Kontexte 36 (2013) z. 1-2, s. 72. Ponieważ nietypowa dla Łukasza składnia czasownika proskyneō z datiwem $(\mathrm{Dz} 7,43)$ pochodzi z Wj 32,8 lub Pwt 4,19 LXX, nie mamy tu do czynienia z jakąś przed-Łukaszową tradycją, jak sądzi G. D. K i l p a t r i c k, Some Quotations in Acts, w: J. K r e m e r (red.), Les Actes des Apôtres: Traditions, rédaction, théologie, BETL 48, Louvain 1979, s. 83.

8 Por. R. P e s c h, Die Apostelgeschichte, EKK 5, Neukirchen-Vluyn-Ostfildern 2012, s. 255; H. B r a u n, Geschichte des Gottesvolkes und christliche Identität: Eine kanonisch-intertextuelle Auslegung der Stephanusepisode Apg 6,1-8,3, WUNT 2.279, Tübingen 2010, s. 321.

9 Por. J. Z m i j e w s k i, Die Apostelgeschichte, RNT, Regensburg 1994, s. 325.

10 Inaczej sądzi R. P e s c h, Apostelgeschichte, s. 256. 
Trzecią, najważniejszą różnicę w stosunku do tekstu Am 5,25-27 stanowi użycie w Dz 7,43 nazwy geograficznej „Babilon” w miejsce toponimu „Damaszek”. Toponim ten występuje zarówno w hebrajskim, jak i greckim tekście Am 5,27 (por. także CD 7,15.19; 4Q266 frag. 3 kol. 3,20 ). Trudno zatem przypuszczać, by św. Łukasz korzystał tu z jakiejś innej wersji tekstu Księgi Amosa. Poza tym, nazwa „Babilon”, odnosząca się do miejsca przesiedlenia Izraelitów w Dz 7,43, wprowadza do mowy Szczepana ewidentną anachronię, gdyż po niej znów pojawia się w tekście postać Mojżesza (Dz 7,44), a następnie postaci Jozuego, Dawida i Salomona (Dz 7,45-47). ${ }^{11}$ Przesiedlenie ,poza Babilon” wprowadza motyw znany z innych ksiąg Starego Testamentu (por. np. 2Krl 24,16). W kontekście mowy Szczepana ukazuje on cały dom Izraela jako będący niejako stale na wygnaniu w dalekiej diasporze, ${ }^{12}$ gdzie kontakt ze świątynnym kultem Jahwe jest niemożliwy, chociażby z tego powodu, że jerozolimska świątynia została w czasie wygnania Judejczyków do Babilonu zburzona. Aluzja do wygnania poza Babilon (Dz 7,43) pasuje więc także do sytuacji Żydów po zburzeniu świątyni jerozolimskiej w 70 r. po Chr. ${ }^{13}$ Obraz ten wyraźnie dostosowany jest również do głównej myśli końcowej części mowy Szczepana, która ukazuje Izraela jako w istocie pozbawionego prawdziwego kultu Boga (Dz 7,48-53).

Można zatem stwierdzić, że św. Łukasz wykorzystał w swej kompozycyjnej pracy tekst Am 5,25-27 w wersji Septuaginty, ale w kilku miejscach zmodyfikował go stosownie do własnych celów teologiczno-retorycznych. ${ }^{14}$

11 Por. T. H o $1 \mathrm{t} \mathrm{z,} \mathrm{Untersuchungen} \mathrm{über} \mathrm{die} \mathrm{alttestamentlichen} \mathrm{Zitate} \mathrm{bei} \mathrm{Lukas,}$ TU 104, Berlin 1968, s. 87-88; E. R i c h a rd, The Creative Use of Amos by the Author of Acts, NovT 24/1982, s. 41.

12 Por. C. S. K e e n e r, Acts: An Exegetical Commentary, t. 2, Grand Rapids, Mi. 2013, s. 1412.

13 Por. C. C. H i 11, Acts 6:1-8:4: division or diversity? w: B. W it h e r i nto $\mathrm{n}$ III (red.), History, Literature and Society in the Book of Acts, Cambridge 1996, s. 148; R. I. P e r v o, Acts: A Commentary, Hermeneia, Minneapolis 2009, s. 189; R. K e s s le r, Wüstenzeit, s. 73-74.

14 Por. T. Holt z, Untersuchungen, s. 14-19; P. A. P a u 1 o, Problème, s. 64; J. J e r v e 11, Die Apostelgeschichte, KEK 3, Göttingen 1998, s. 242-243. 


\section{Cytat z Am 9,11-12 LXX w Dz 15,16-18}

Drugi cytat z Księgi Amosa (Am 9,11-12) w Dziejach Apostolskich (Dz 15,16-18) pochodzi z końcowej części księgi, zapowiadającej odbudowę dynastii Dawidowej w Jerozolimie (Am 9,11-15). ${ }^{15}$ Cytat ten został zastosowany przez św. Łukasza jako fragment przemówienia Jakuba na tzw. soborze jerozolimskim (Dz 15,13-21).

Forma greckiego cytatu z Am 9,11-12 w Dz 15,16-18 znów generalnie zgadza się z wersją Septuaginty, jednakże widoczne są także wyraźne różnice w stosunku do tej najbardziej rozpowszechnionej wśród Żydów z diaspory greckiej wersji Biblii.

Pierwszą wyraźną zmianą w stosunku do wersji Septuaginty jest zastąpienie rozpoczynającego Amosowe zdanie wyrażenia „w owym dniu", które użyte zostało zarówno w hebrajskim, jak i greckim tekście Am 9,11 (en tē hēmera ekeinē), dość ogólnikowym określeniem „potem” (meta tauta: Dz 15,16). Zmianę tę można wyjaśnić jako efekt odmiennej perspektywy czasowej ukazywanej w cytowanej wypowiedzi. To, co dla Amosa było mającą nastąpić „w owym dniu” przyszłością, dla Jakuba staje się następującą po przeszłych wydarzeniach teraźniejszością.

Drugą wyraźną zmianą w stosunku do wersji Septuaginty jest dwukrotne opuszczenie słowa „wskrzeszę” (Dz 15,16), występującego zarówno w hebrajskiej (por. także CD 7,16; 4Q174 [Flor.] frag. 1_2 kol. 1,12-13), jak i greckiej wersji Am 9,11 (anistēmi). Zmiana ta w przypisanej Jakubowi wypowiedzi mogła być efektem Łukaszowego dążenia do podkreślenia różnicy między Piotrem, który zgodnie z Pawłowym przekazem $(1$ Kor 15,4$)$ był pierwszym świadkiem, głosicielem i „odtwórcą” mocy wskrzeszenia Jezusa (anistēmi:

15 Jak wspomniano wyżej, oba teksty z Księgi Amosa, cytowane przez św. Łukasza (Am 5,26-27; 9,11), wykorzystane zostały łącznie w Dokumencie Damasceńskim (CD 7,14-16). Ponieważ jednak św. Łukasz wykorzystał je w różnych miejscach swego dzieła (Dz 7,42-43; 15,16-18), interpretował je wyraźnie odmiennie niż CD 7,14-19, a przy tym najwyraźniej korzystał z greckiej wersji Septuaginty, trudno przypuszczać, by w swej intertekstualnej działalności sugerował się tym właśnie hebrajskim tekstem; por. P. A. P a u 1 o, Problème, s. 126-130. 
Dz 2,24.32; 3,26; 9,34.40-41; 10,41; 12,7), a Jakubem, który był pod tym względem dużo bardziej odległy (por. 1Kor 15,7).

Trzecia zmiana w stosunku do tekstu Septuaginty polega na wprowadzeniu w miejsce pierwszego wystąpienia słowa „wskrzeszę” czasownika „nawrócę” (anastrephō: Dz 15,16) ${ }^{16}$ którego nie ma nie tylko w tekście greckim, ale także w odpowiadającym mu tekście hebrajskim Am 9,11 (por. także CD 7,16; 4Q174 [Flor.] frag. 1_2 kol. 1,12-13). Efektem tej zamiany jest zdanie złożone, które jest ewidentnie niespójne semantycznie: „Potem nawrócę i odbuduję namiot Dawida" (Dz 15,16). Łukasz pragnął tu najprawdopodobniej nawiązać do wyrażonej wcześniej idei wygnania Izraelitów poza Babilon (Dz 7,43), które zakończone zostaje dzięki działaniu Boga. Powrót ten musi być jednak poprzedzony nawróceniem Żydów do nowego sposobu zbawczego działania Boga w Jezusie (Dz 15,16).

Kolejna Łukaszowa modyfikacja tekstu Księgi Amosa w wersji Septuaginty polega na wprowadzeniu w miejsce drugiego wystąpienia słowa „wskrzeszę” czasownika „wyprostuję” (anorthoō: Dz 15,16), który również nie występuje nie tylko w greckim, ale także w odpowiadającym mu hebrajskim tekście Am 9,11. Także w tym przypadku powstałe w wyniku Łukaszowej modyfikacji zdanie złożone jest semantycznie dość niespójne: „Ruiny jego odbuduję i wyprostuję go" (Dz 15,16). Czasownik anorthoo, wraz z poprzedzającym go anoikodomeō, tworzy jednak lingwistyczne echo tekstu 2Sm 7,13 LXX, który ma wyraźny wydźwięk mesjański. ${ }^{17}$

16 Zachowujemy tu przechodni sens czasownika anastrephō rozumianego jako echo użytego w znaczeniu przechodnim czasownika anistēmi w Am 9,11 LXX. Czasownik anastrephō może być jednak także rozumiany w Dz 15,16 w sensie nieprzechodnim: ,powrócę”.

17 Por. G. R o s s é, Atti degli Apostoli: Commento esegetico e teologico, Roma 1998, s. 577 przyp. 87; W. E. G 1 e n n y, The Septuagint and Apostolic Hermeneutics: Amos 9 in Acts 15, Bulletin for Biblical Research 22/2012, s. 19-20. Nie chodzi tu więc o literalnie pojmowaną budowę mesjańskiej świątyni, jak sądzi R. B a u c k $\mathrm{h}$ a $\mathrm{m}$, James and the Gentiles (Acts 15.13-21), w: B. W it h e r i n g t o n III (red.), History, s. 157-160. 
Następną ewidentną zmianą cytowanego z Septuaginty tekstu Księgi Amosa jest opuszczenie okolicznika czasu ,jak za dawnych dni" (Dz 15,16), obecnego zarówno w greckiej, jak i hebrajskiej wersji Am 9,11, a odnoszącego się do odnowienia namiotu, czyli dynastii Dawida. Celem św. Łukasza było tu prawdopodobnie uniknięcie idei nostalgicznego cofania się w historii do dawnej dynastii Dawidowej. ${ }^{18}$

Jeszcze inna Łukaszowa modyfikacja tekstu Septuaginty polega na wprowadzeniu po czasowniku ,szukać” dopełnienia „Pana” (ton kyrion: Dz 15,17), którego brak jest zarówno w greckiej, jak i hebrajskiej wersji Am 9,12. Tym razem motywacja św. Łukasza jest dość oczywista. Było nią pragnienie wyjaśnienia niejasnego tekstu greckiego Am 9,12 LXX. Na skutek błędnego odczytania hebrajskiego czasownika yrš (,„wziąć w posiadanie”) jako $d r s ̌$ (,„szukać”), zaś rzeczownika ' $d w m$ („Edom”) jako ' $d m$ (,,człowiek”), hebrajskie zdanie „aby posiedli resztę Edomu” zostało w Septuagincie przetłumaczone jako „aby szukali pozostali z ludzi”. ${ }^{19}$ Hebrajskie dopełnienie ,resztę Edomu” stało się więc w Am 9,12 LXX podmiotem: ,pozostali z ludzi". W efekcie, w greckim zdaniu Am 9,12 LXX brakuje dopełnienia, a więc nie wiadomo, kogo owi ,pozostali z ludzi” mają szukać. Święty Łukasz wyjaśnił tę semantyczną zagadkę, dodając własne dopełnienie: „Pana” (Dz 15,17), które treściowo pasuje do reszty zdania Am 9,12 $\mathrm{LXX}^{20}$

Ostatnią wyraźną modyfikacją zaczerpniętego z Septuaginty tekstu Am 9,12 jest dodanie na końcu cytatu wyrażenia gnōsta ap' aiōnos (,znane od wieków”: Dz 15,18), którego brak jest zarówno w greckim, jak i hebrajskim tekście Am 9,12. Wyrażenie to jest dość sztucznie dodane do poprzedniego zdania: „Mówi Pan, który czyni te rzeczy" (Dz 15,17; por. Am 9,12 LXX). Jego pochodzenie też jest bardzo niejasne, choć treściowo i lingwistycznie przypomina ono

18 Por. C. K. B a r ret t, The Acts of the Apostles, ICC, t. 2, Edinburgh 1998, s. 725 .

19 Por. P. A. P a u 1 o, Problème, s. 76-77.

20 Por. L. T. Joh n s o n, The Acts of the Apostles, SP 5, Collegeville, Minn. 1992, s. 265; E. R i c h a r d, Creative, s. 46; W. E. G 1 e n n y, Septuagint, s. 13. 
jakiś tekst starotestamentalny. ${ }^{21}$ Możliwe starotestamentalne źródła tego dodatku to Iz 45,21 LXX, ${ }^{22}$ względnie Ez 36,32 LXX, poza użyciem w nich zbliżonego słowa gnōsin (Iz 45,21 LXX), względnie gnōston (Ez 36,32 LXX), są jednak lingwistycznie odległe od zastosowanego przez św. Łukasza krótkiego, prostego wyrażenia. ${ }^{23}$ Pochodzenie tego zagadkowego dodatku da się adekwatnie wyjaśnić tylko po dokładnej intertekstualnej analizie Łukaszowego opisu tzw. soboru jerozolimskiego (Dz 15,6-29) na tle listów Pawłowych, a zwłaszcza Listu do Galatów.

\section{Echa Ga 2,9 w Dz 15,6-21}

Łukaszowy opis tzw. soboru jerozolimskiego (Dz 15,6-29) jest dość zaskakujący. W istocie składa się on jedynie z dwóch dłuższych wypowiedzi: Piotra (Dz 15,7-11) oraz Jakuba (Dz 15,13-21), ${ }^{24}$ zakończonych opisem wysłania posłańców i listu do wiernych w Antiochii, Syrii i Cylicji (Dz 15,22-29). ${ }^{25}$ Święty Łukasz poświęcił zaskakująco mało miejsca udziałowi dwóch głównych bohaterów poprzedniej sekcji swej narracji, a mianowicie Barnaby i Pawła (por. Dz 13-14), referując tylko ogólnikowo ich wypowiedzi (Dz 15,12). ${ }^{26}$ Dokładna analiza intertekstualna Łukaszowego opisu „soboru jerozolimskiego” (Dz 15,6-29) na tle Listu do Galatów wskazuje, że zaskakująca struktura Łukaszowego opisu jest $\mathrm{w}$ istocie odzwierciedleniem tematycznej struktury Pawłowej relacji z tego apostolskiego zebrania (Ga 2,7-9).

21 Por. T. H o 1 t z, Untersuchungen, s. 22; M. D ö m e r, Das Heil Gottes: Studien zur Theologie des lukanischen Doppelwerkes, BBB 51, Köln-Bonn 1978, s. 179.

22 Por. J. A. F it z y e r, The Acts of the Apostles, AB 31, New York (i in.) 1998, s. 556; D. L. B o c k, Acts, BECNT, Grand Rapids, Mi. 2008, s. 505; W. E. G 1 e n n y, Septuagint, s. 14.

23 Por. C. K. B a r ret t, Acts, t. 2, s. 728.

24 Por. M. D ö m e r, Heil, s. 182.

25 Por. A. W e is e r, Die Apostelgeschichte, t. 2, ÖTKNT 5/2, Gütersloh-Würzburg 1985, s. 366.

26 Por. R. P e s c h, Apostelgeschichte, s. 73. 
Wielu badaczy dostrzegło już, że relacjonowana przez św. Łukasza wypowiedź Piotra (Dz 15,7-11) w rzeczywistości ukazuje główne tezy teologii Pawłowej, zwłaszcza głoszenie Ewangelii wolnej od wymogów żydowskiego Prawa (Dz 15,10-11; por. Ga 2,16 itp.). ${ }^{27}$ Święty Łukasz ewidentnie znał główne tezy teologii Pawłowej, więc taka zbieżność mogła być wynikiem jedynie ogólnego zaznajomienia się przez Łukasza z historią i głównymi cechami misji Apostoła Narodów.

Należy jednak zauważyć także, że wewnętrzna struktura etopeicznej wypowiedzi, włożonej przez św. Łukasza w usta Piotra (Dz 15,7-11), wiernie oddaje strukturę Pawłowej relacji na temat apostolskiej aktywności Piotra, znanej z konkretnego literackiego tekstu, a mianowicie Listu do Galatów (Dz 2,7-9).

Otwierające wypowiedź Piotra (Petros) stwierdzenie, że Bóg wybrał go do głoszenia ewangelii (to euaggelion: Dz 15,7) dla wierzących (pisteuō), treściowo, a po części także leksykalnie, odzwierciedla początkowe stwierdzenie Pawłowe, iż Piotrowi (Petros) zostało powierzone ( pisteuō) głoszenie ewangelii (to euaggelion), podobnie jak zostało ono powierzone Pawłowi (Ga 2,7). ${ }^{28}$ Święty Łukasz, opierając się na Pawłowej idei komplementarności ewangelii Piotrowej i Pawłowej (Ga 2,7), twórczo przetworzył Pawłową relację, sugerując, że Piotrowi powierzone zostało głoszenie ewangelii nie tylko wśród obrzezanych (Ga 2,7), ale także wśród pogan (Dz 15,7; por. 9,32-11,18).

Kolejne zdania w wypowiedzi Piotra, odwołujące się do doświadczenia działania Boga w poganach (ta ethnee: por. Dz 15,7) tak samo jak w Żydach (Dz 15,8-9; por. 11,15-17), treściowo, a po części także leksykalnie, odzwierciedlają kolejne zdania z Listu do Galatów, odwołujące się do działania Boga w poganach (ta ethnē) tak samo jak w obrzezanych (Ga 2,8). Ponieważ użyty przez Pawła

27 Por. J. Z m ij e w s k i, Apostelgeschichte, s. 561, 566-567; P. N. Ta ra z i, The New Testament: An Introduction, t. 2: Luke and Acts, Crestwood, NY 2001, s. 241; R. I. P e r v o, Dating Acts: Between the Evangelists and the Apologists, Santa Rosa, Calif. 2006, s. 92-95.

28 Por. tamże, s. 92. 
czasownik energeō („działać”: Ga 2,8) odnosi się w Pawłowej teologii zarówno do Boga (1Kor 12,6), jak i do Ducha Świętego (1Kor 12,11), św. Łukasz opisowo oddał teologiczne znaczenie tego czasownika, przywołując w jednym zdaniu obraz działania Boga przez Ducha Świętego (Dz 15,8).

Kolejna część wypowiedzi Piotra, deprecjonująca wartość żydowskiego Prawa (Dz 15,10), a następnie odwołująca się do wiary w moc łaski (charis), która daje zbawienie Żydom tak samo jak poganom (Dz 15,11), treściowo, a po części także leksykalnie, odzwierciedla kolejne Pawłowe stwierdzenie, że jerozolimscy przywódcy poznali łaskę (charis), która została dana Pawłowi (Ga 2,9a). Zaskakująca w ustach żydowskiego apostoła Piotra deprecjacja Prawa jako zniewalającego jarzma (zygos), która w istocie bardziej pasuje do teologii Pawła (por. Ga 5,1: zygos) niż Piotra, ${ }^{29}$ a następnie odwołanie się do zbawczego znaczenia wiary i łaski (Dz 15,10-11), obrazowo, za pomocą idei wyrażonych w innych częściach Listu do Galatów (Ga 2,16.19-21 itp.; por. także Ef 2,8), ${ }^{30}$ ukazuje więc Pawłową ideę, że Piotr uznał łaskę daną Pawłowi (Ga 2,9a).

Następna, niejako wtrącona, wzmianka na temat cudownego Bożego działania przez Barnabę i Pawła wśród pogan (ta ethnē: Dz 15,12) $)^{31}$ ilustruje następne zdanie z Pawłowej relacji, dotyczące wyjątkowej łaski danej przez Boga Pawłowi (Ga 2,9b), domyślnie w celu apostołowania wśród pogan (ta ethnē: por. Ga 2,8). Barnaba został tu dodany przez św. Łukasza (por. także Dz 13-14) na podstawie wzmianki o nim wraz z Pawłem w Ga 2,1.

Następująca dalej wypowiedź Jakuba (Dz 15,13-21) w sekwencyjnie zorganizowanej, intertekstualnej relacji Łukaszowego tekstu Dz 15,6-29 do Ga 2,7-9 strukturalnie odpowiada zatem wzmiance

29 Por. P. N. Ta r a z i, Introduction, t. 2, s. 241; R. I. P e r v o, Dating, s. 94.

30 Por. tamże, s. 93-94.

31 Por. R. P e s c h, Apostelgeschichte, s. 73, który w sposób typowy dla egzegezy historyczno-krytycznej argumentuje, że Dz 15,12b jest śladem przed-Łukaszowej tradycji (Dz 15,1-4.12b), włączonej w inną przed-Łukaszową tradycję (Dz 15,5-12a.13-33). 
o Jakubie w Ga 2,9c. Jakub został jednak przez św. Łukasza przedstawiony zupełnie inaczej niż Piotr. O ile bowiem Piotr początkowo przynajmniej sympatyzował z Pawłem i w jakiś sposób akceptował jego linię halachiczno-teologiczną (por. Ga 1,18; 2,7-8.11a.12ab), o tyle Jakub zachowywał wobec Pawła duży dystans, stając się z czasem, przynajmniej pośrednio, jego największym krytykiem (por. Ga 1,19; 2,12c. f). Dlatego też włożona przez św. Łukasza w usta Jakuba wypowiedź, ilustrująca Pawłową myśl, że Jakub wyraził zgodę na ewangelizację pogan w sposób zgodny z Pawłową teologią (Ga 2,9ab), a więc w wolności od większości wymogów żydowskiego Prawa (por. Ga 2,12b.16.19-21 itp.), w istocie dotyczy tego zagadnienia tylko częściowo (Dz 15,13-14.19-21). Zasadniczą część wypowiedzi Jakuba (Dz 15,16-18) stanowi zaś długi skrypturystyczny cytat z Am 9,11-12, odnoszący się do mesjańskich nadziei związanych z dynastią Dawidową - tak przynajmniej interpretowano tekst Am 9,11 w 4Q174 [Flor.] frag. 1_2 kol. 1,11-13.32 Święty Łukasz, stosując i (jak wykazano wyżej) odpowiednio modyfikując cytat z Am 9,11-12, by wyraźniej wyrażał idee mesjańskie (por. zwłaszcza 2Sm 7,13 LXX), w etopeiczny sposób ukazał więc Jakuba jako interesującego się głównie żydowskim mesjanizmem, zaś ewangelizacją pogan tylko ubocznie. ${ }^{33}$ Podobny obraz Jakuba i jego zwolenników ukazany został także w Dz 21,20-25: ewangelizacja pogan jest tam tylko wspomniana, natomiast główny problem dotyczy kwestii zachowywania żydowskiego Prawa. ${ }^{34}$

32 Por. M. N e u b r a n d, Israel, die Völker und die Kirche: Eine exegetische Studie zu Apg 15, SBB 15, Stuttgart 2006, s. 147-150.

33 Fakt niedokładnego treściowo dopasowania cytatu z Am 9,11-12 do problemu omawianego w kontekście (Dz 15,6-29) zauważył m. in. Alfons Weiser. Wyciągnął on jednak z tego faktu typowy dla egzegezy historyczno-krytycznej wniosek, że cytat z Am 9,11-12 pochodzi z przed-Łukaszowego zbioru cytatów starotestamentalnych; A. W e is e r, Apostelgeschichte, t. 2, s. 373.

34 Z tego względu trudno zgodzić się z sugestią, że Łukaszowy Jakub pojmował Pawłową ewangelizację pogan jako konieczny warunek do realizacji mesjańskiego królestwa, jak sądzi (powołując się na Pawłowy tekst Rz 11,25-27) M. N e u b r a n d, Israel, s. 218-219, 251. 
Z tego też powodu w usta Jakuba włożony został przez św. Łukasza skrypturystyczny cytat z Am 9,11-12, a nie np. Iz 42,6-7; 49,6 (przywołany w Dz 13,47) lub Za 2,15, ${ }^{35}$ które to teksty w dużo lepszy sposób nadawałyby się do uzasadnienia idei misji wśród pogan opartej na wypowiedziach biblijnych proroków (por. Dz 15,15).

Jedynym leksykalnym śladem intertekstualnego wykorzystania Pawłowej wypowiedzi na temat Jakuba jako uznającego (ginōskō) łaskę daną Pawłowi (Ga 2,9ab) jest intrygujący, ewidentnie sztuczny dodatek dołączony przez św. Łukasza do długiego cytatu z Am 9,11-12 LXX, a mianowicie stwierdzenie dotyczące rzeczy znanych (gnōsta) od wieków (Dz 15,18). Ponieważ w Łukaszowej prezentacji Jakub zgodził się na Pawłową misję wśród pogan niejako przy okazji jego zainteresowań żydowskim mesjanizmem, brak w wypowiedzi Jakuba stwierdzenia wprost popierającego stanowisko Pawła. Uznanie (ginōskō) łaski danej Pawłowi (Ga 2,9ab) wyrażone zaś zostaje w dostosowany do mentalności Jakuba, quasi-skrypturystyczny sposób, ${ }^{36}$ a mianowicie w postaci stwierdzenia, że Boże sposoby działania znane (gnōsta) są od wieków (Dz 15,18). Dodatek do cytatu z Am 9,11-12 LXX w Dz 15,18 nie pochodzi więc z jakiejś przed-Łukaszowej tradycji lub zbioru „testimoniów”, ${ }^{37}$ ale jest elementem celowo wprowadzonym przez św. Łukasza, aby skonstruować intertekstualną aluzję do Ga 2,9ab.

Końcowy opis wysłania z Jerozolimy wraz z Barnabą i Pawłem posłańców i listu do wiernych pogańskiego pochodzenia (ta ethnē) w Antiochii, Syrii i Cylicji (Dz 15,22-29) treściowo, a po części także leksykalnie, ilustruje zaś końcowe stwierdzenie Pawła, że

35 Por. R. P e s c h, Apostelgeschichte, s. 80; W. R a d 1, Rettung in Israel, w: C. B u s m a n n, W. R a d 1 (red.), Der Treue Gottes trauen: Beiträge zum Werk des Lukas, Festschrift G. Schneider, Freiburg-Basel-Wien 1991, s. 54; C. S. K e e n e r, Acts, t. 3, Grand Rapids, Mi. 2014, s. 2257.

36 Por. M. D ö m e r, Heil, s. 185.

37 Za taką hipotezą, charakterystyczną dla starszych prac prowadzonych metodą historyczno-krytyczną, opowiadał się m. in. G. L o h f i n k, Die Sammlung Israels: Eine Untersuchung zur lukanischen Ekklesiologie, SANT 39, München 1979, s. 59, 88. 
jerozolimscy przywódcy podali Pawłowi i Barnabie prawicę na znak wspólnoty, aby mogli iść z misją do pogan (ta ethnē: Ga 2,9c-g). Dość deprecjonująco użyty przez Pawła czasownik dokeō (,wydawać się": Ga 2,9c) użyty został również przez św. Łukasza, ale w znaczeniu dużo bardziej pozytywnym (,uznać za dobre, postanowić": Dz 15,22.25.28). Poza tym, św. Łukasz, w typowy dla swego obrazu Kościoła sposób, opuścił zawstydzającą wzmiankę Pawła dotyczącą wysuniętego przez jerozolimskich przywódców żądania finansowego wspierania ich judeochrześcijańskiej wspólnoty przez nawróconych pogan (Ga 2,10; por. jedynie przepracowanie tego tematu w Dz 21,23-26).

\section{Wykorzystanie listów Pawłowych w Dziejach Apostolskich}

Świadome uzupełnienie cytatu z Am 9,11-12 o fragment stanowiący leksykalną aluzję do Ga 2,9 w celu stworzenia etopeicznej wypowiedzi, włożonej w usta Jakuba i ilustrującej jego dość powściągliwy stosunek do działalności Apostoła Narodów (Dz 15,18), rzuca ciekawe światło na szerszy problem znajomości i wykorzystania listów Pawłowych, a nie tylko ogólnych wiadomości na temat Pawła, przez św. Łukasza. ${ }^{38}$

Kwestia literackiego wykorzystania listów Pawłowych przez św. Łukasza od dawna jest przedmiotem debaty wśród biblistów. Aż do XIX w. generalnie przyjmowano, że Dzieje Apostolskie zostały napisane przez Łukasza, który był towarzyszem podróży Pawła, naocznym świadkiem licznych wydarzeń opisanych w Dziejach Apostolskich, a w konsekwencji także osobą mającą bezpośredni dostęp do Pawła i do innych wiarygodnych źródeł informacji dotyczących najwcześniejszego etapu rozwoju chrześcijaństwa. Nie było więc powodu, by zadawać pytanie, czy dane i idee przedstawione w Dziejach

38 Na ten temat zob. m. in. B. A d a m c z e w s k i, Heirs of the Reunited Church: The History of the Pauline Mission in Paul's Letters, in the So-Called Pastoral Letters, and in the Pseudo-Titus Narrative of Acts, Frankfurt am Main (i in.) 2010, s. 83-87. 
Apostolskich są w jakiś sposób oparte na danych i ideach zawartych w listach Pawłowych.

To dość powierzchowne rozumienie Dziejów Apostolskich zmieniło się w połowie XIX w., gdy Ferdynand Christian Baur wykazał, że Dzieje Apostolskie nie są bynajmniej ideologicznie neutralne w ich sposobie przedstawiania historii wczesnego chrześcijaństwa. Niemiecki badacz argumentował, że główną ideę Dziejów Apostolskich stanowi sztucznie paralelne przedstawienie postaci Piotra i Pawła, tak że na przykład Dz 10 zawiera pośrednią Piotrową legitymizację wizji Pawła, które znane są z jego listów. ${ }^{39}$

W drugiej połowie XIX w. literackie wykorzystanie listów Pawłowych przez św. Łukasza było uznawane za oczywiste przez, dla przykładu, Eduarda Zellera ${ }^{40}$ i Augusta Jacobsena. ${ }^{41}$ Aby wyjaśnić różnice między danymi zawartymi w listach Pawłowych i w Dziejach Apostolskich, inni badacze sugerowali że - np. Łukasz oprócz listów Pawłowych wykorzystywał także inne źródła ${ }^{42}$ - Łukasz wykorzystywał listy Pawłowe głównie w literackich mowach w Dziejach Apostolskich, ${ }^{43}$ względnie Dzieje Apostolskie zostały skomponowane przez przynajmniej dwu różnych redaktorów. ${ }^{44}$ Ponadto Gustav Volkmar argumentował, że Łukasz w znacznym, stopniu przepracował źródła w procesie kompozycji swego opowiadania. ${ }^{45}$ Niektórzy

39 F. C. B a u r, Paulus, der Apostel Jesu Christi: Ein Beitrag zu einer kritischen Geschichte des Urchristentums, Stuttgart 1845, s. 6-7, 242.

40 E. Z e 11 e r, Die Apostelgeschichte nach ihrem Inhalt und Ursprung kritisch untersucht, Stuttgart 1854, s. 518-519.

${ }^{41}$ A. J a c o b s e n, Die Quellen der Apostelgeschichte, Berlin 1885, passim; t e n ż e, Über die lukanischen Schriften, Zeitschrift für wissenschaftliche Theologie 31/1888, s. 148-155.

42 G. Volk m a r, Paulus von Damascus bis zum Galaterbrief, Zürich 1887, s. 13-14; C. C 1 e m e n, Die Chronologie der paulinischen Briefe aufs Neue untersucht, Halle a. S. 1893, s. 67-161.

${ }^{43}$ H. S c h u 1 z e, Die Unterlagen für die Abschiedsrede zu Milet in Apostelgesch. 20, 18-38, Theologische Studien und Kritiken 73/1900, s. 119-125; W. S o 1 t a u, Die Herkunft der Reden in der Apostelgeschichte, ZNW 4/1903, s. 133-138.

${ }^{44}$ C. C1 e m e n, Chronologie, s. 100-146, 156-161.

45 G. Volk m a r, Paulus, s. 60-62. 
badacze postulowali również zależność Dziejów Apostolskich także od dzieł Józefa Flawiusza. ${ }^{46}$

Dla kontrastu, w drugiej połowie XX w. tylko mała grupa biblistów utrzymywała, że Łukasz znał i literacko wykorzystał listy Pawła, względnie też dzieła Józefa Flawiusza. ${ }^{47}$ Część badaczy optowała za Łukaszowym użyciem hipotetycznego, historycznie wiarygodnego lecz, niestety, zaginionego źródła dotyczącego podróży Pawła ${ }^{48}$ ewentualnie też innych źródeł. ${ }^{49}$ Mała grupa biblistów argumentowała, że Łukasz znał jakieś dane biograficzne dotyczące Pawła z przynajmniej jednego z jego listów, z tym że twórczo przetworzył w swej narracji np. informację o pochodzeniu Pawła ze szczepu Beniamina we wzmiankę o analogicznym pochodzeniu Saula (Dz 13,21), ${ }^{50}$ względnie informacje o pisaniu przez Pawła listów we wzmiankę o niesionych przez niego listach (Dz 9,2). ${ }^{51} \mathrm{~W}$ szczególności, Gerd Lüdemann odnowił dziewiętnastowieczną hipotezę Gustava Volkmara, że Łukasz przerobił dwie podróże Pawła do Jerozolimy, wzmiankowane w jego listach, w cztery podróże opisane w Dziejach Apostolskich (Ga 2,1-10a w Dz 15 i Dz 18; Ga 2,10b w Dz 11

46 C. C 1 e m e n, Chronologie, s. 157. Potem m in. także H. L. R a m s e y, The Place of Galatians in the Career of Paul, Ann Arbor, Mi. 1961, s. 92-94.

47 Tamże, s. 92-94; B. T h i e r in g, The Acts of the Apostles as Early Christian Art, w: E. C. B. M a c L a u r in (red.), Festschrift G. W. Thatcher, Sydney 1967, s. $184-189$.

48 J. C. H u r d, The Origin of I Corinthians, London 1965, s. 29-30; C. B u c k, G. Ta y lo r, Saint Paul: A Study of the Development of His Thought, New York 1969, s. 192-193.

49 G. L ü d e m a n n, Paulus, der Heidenapostel, t. 2, Antipaulinismus im frühen Christentum, FRLANT 130, Göttingen 1983, s. 91-94; t e n ż e, Das frühe Christentum nach den Traditionen der Apostelgeschichte: Ein Kommentar, Göttingen 1987, s. 18-24; t e n ż e, Paulus, der Gründer des Christentums, Lüneburg 2001, s. 59.

50 M. S. En s 1 i n, Luke, the Literary Physician, w: D. E. A u n e (red.), Studies in New Testament and Early Christian Literature, Festschrift A. P. Wikgren, NovTSup 33, Leiden 1972, s. 141-143.

51 A. L i n d e m a n n, Paulus im ältesten Christentum: Das Bild des Apostels und die Rezeption der paulinischen Theologie in der frühchristlichen Literatur bis Marcion, BHTh 58, Tübingen 1979, s. 165-173. 
i Dz 24), ${ }^{52}$ argumentując, że Łukasz zmienił drugą podróż Pawła do Jerozolimy w trzy podróże, opisane w Dz 11; 15; 18, tak jak potroił opis nawrócenia Pawła w Dz 9; 22; $26 .{ }^{53}$

W ostatnich latach część biblistów, zwłaszcza niemiecko i francuskojęzycznych, nadal mocno sprzeciwia się hipotezie jakiejkolwiek literackiej zależności Dziejów Apostolskich od listów Pawłowych. Dla przykładu, katolicki biblista niemiecki Alfred Suhl stwierdził wprost, że Łukasz nie wykorzystywał w swym dziele listów Pawła. ${ }^{54}$ Katolicka biblistka francuska Odile Flichy przeanalizowała postać Pawła w Dziejach Apostolskich z narratologicznego punktu widzenia i stwierdziła, że Paweł funkcjonował po prostu jako postać emblematyczna dla chrześcijańskich odbiorców dzieła Łukasza. ${ }^{55}$ Szwajcarski biblista Daniel Marguerat argumentuje z kolei, że między Dziejami Apostolskimi a listami Pawłowymi jest bardzo niewiele zbieżności językowych, a więc autor Dziejów musiał oprzeć się nie na listach Pawła, ale na ustnie przekazywanych wypowiedziach apostoła, jakiejś historii jego życia i jakimś streszczeniu jego teologii. ${ }^{56}$ Natomiast niemiecki biblista Enno Popkes, choć argumentuje, że teologia Łukaszowa na tyle różni się od teologii Pawłowej, że trudno jest wykazać bezpośrednią zależność literacką Dziejów Apostolskich od listów Pawłowych, to jednak ostatecznie kwestię możliwego Łukaszowego wykorzystania listów apostoła pozostawia otwartą. ${ }^{57}$

52 G. Volk m a r, Paulus, s. 60-62.

53 G. L ü d e m a n n, Paulus, der Heidenapostel, t. 1, s. 165-169.

54 A. S u h 1, Die Briefe des Paulus: Eine Einführung, SBS 205, Stuttgart 2007, s. 15 .

55 O. F l i c hy, La figure de Paul dans les Actes des Apôtres: Un phénomène de réception de la tradition paulinienne à la fin du premier siècle, LeDiv 214, Paris 2007, s. 322.

56 D. M a r g u e r a t, Paul après Paul: une histoire de réception, NTS 54/2008, S. 324-335.

57 E. E. P o p k e s, Die letzten Worte des lukanischen Paulus: Zur Bedeutung von Act 28,25-28 für das Paulusbild der Apostelgeschichte, w: J. F r e y i in. (red.), Die Apostelgeschichte im Kontext antiker und frühchristlicher Historiographie, BZNW 162, Berlin-New York 2009, s. 618, 624. 
$\mathrm{Z}$ drugiej strony wyraźnie powiększa się w ostatnich latach, zwłaszcza w środowisku amerykańskim, grupa biblistów, którzy optują za jakimś stopniem wykorzystania listów Pawłowych w Dziejach Apostolskich. Dla przykładu, pracujący w Stanach Zjednoczonych prawosławny biblista palestyński, Paul Nadim Tarazi, argumentuje, że Łukasz wykorzystał List do Galatów i inne listy Pawłowe w kompozycji Dziejów Apostolskich. ${ }^{58}$ Amerykański biblista Paul Elbert zauważył, że w swym wykorzystaniu listów Pawłowych Łukasz mógł postępować bardzo swobodnie, zgodnie ze wzorami przyjętymi dla starożytnych kompozycji narracyjno-retorycznych, a opisywanymi teoretycznie m. in. przez Teona z Aleksandrii. ${ }^{59}$ Katolicki biblista amerykański, Gregory Tatum, podobnie stwierdził, że Łukasz mógł w znacznym stopniu przetworzyć swój materiał źródłowy, obejmujący także listy Pawłowe, tak jak przerobił on np. wcześniejszy materiał w perykopie o wystąpieniu Jezusa w Nazarecie (Łk 4,16-30). ${ }^{60}$ Inny amerykański biblista, Richard Pervo, przytacza wiele mocnych argumentów na rzecz hipotezy literackiego wykorzystania przez Łukasza nie tylko kolekcji listów Pawłowych, ale także Starożytności $\dot{z} y d o w s k i c h$ Józefa Flawiusza. ${ }^{61}$ Jeszcze inny Amerykanin, Mikeal Parsons, dość ostrożnie sugeruje, że autor i odbiorcy Dziejów Apostolskich prawdopodobnie znali Pawła tylko przez pośrednictwo jego listów. ${ }^{62}$ Dla odmiany, amerykański biblista William Walker od wielu lat przekonuje w swych publikacjach, że dane biograficzne postaci Dziejów Apostolskich świadczą o tym, że Łukasz znał i wykorzy-

58 P. N. T a r a z i, Introduction, t. 2, s. 187-285.

59 P. E $1 \mathrm{~b}$ e r t, Paul of the Miletus Speech and 1 Thessalonians: Critique and Considerations, ZNW 95/2004, s. 264-265.

${ }^{60}$ G. T a t u m, New Chapters in the Life of Paul: The Relative Chronology of His Career, CBQMS 41, Washington, DC 2006, s. 125-126.

${ }_{61}$ R. I. P e r v o, Dating, s. 51-199, 347-358; t e $\mathrm{n} \dot{\mathrm{z}} \mathrm{e}$, The Paul of Acts and the Paul of the Letters: Aspects of Luke as an Interpreter of the Corpus Paulinum, w: D. M a r g u e r a t (red.), Reception of Paulinism in Acts, BETL 229, Leuven-Paris-Walpole, Mass. 2009, s. 147-155.

${ }^{62}$ M. C. P a r s o n s, Luke: Storyteller, Interpreter, Evangelist, Peabody, Mass. 2007, s. $129-139$. 
stywał listy Pawłowe. ${ }^{63}$ Podobnie, na podstawie analizy itinerariów Pawła w jego listach i w Dz 15,36-20,16 amerykański biblista Ryan Schellenberg argumentuje, że Łukasz musiał znać i redakcyjnie wykorzystać prawie całą kolekcję autentycznych listów apostoła. ${ }^{64}$

$\mathrm{Na}$ tę ożywioną, ewidentnie wciąż niezakończoną dyskusję biblistyczną kwestia wykorzystania cytatu z Am 9,11-12 LXX w Dz 15,16-18 rzuca ciekawe światło. Jak wykazano we wcześniejszej części artykułu, komponując swój opis tzw. soboru jerozolimskiego (Dz 15,6-29) św. Łukasz wykorzystał nie tylko ogólne wiadomości lub ustne tradycje dotyczące działalności i poglądów teologicznych Apostoła Narodów, ale także fragment odnoszącej się do tego wydarzenia literacko-retorycznej relacji, zawartej w Liście do Galatów (Ga 2,7-9). Wykorzystanie tego Pawłowego tekstu jest przy tym bardzo charakterystyczne dla techniki literackiej nie tylko św. Łukasza, ale także wielu innych autorów biblijnych - zarówno Starego, jak i Nowego Testamentu. Święty Łukasz kreatywnie wykorzystał tekst Pawłowy we własnym opisie, posługując się przy tym retoryczną techniką etopei (zwanej też prozopopeją), polegającą na literackim charakteryzowaniu danej postaci, zgodnym z zamierzeniem autora dzieła, za pomocą włożonych w jej usta wypowiedzi. Przy całej swej literackiej kreatywności, św. Łukasz zachował jednak sekwencję elementów treściowych, i do pewnego stopnia także leksykalnych, z wykorzystanego przez siebie fragmentu Listu do Galatów: Ga 2,7 w Dz 15,7; Ga 2,8 w Dz 15,8-9; Ga 2,9a w Dz 15,10-11; Ga 2,9b w Dz 15,12; Ga 2,9c w Dz 15,13-21; Ga 2,9c-g w Dz 15,22-29. Wykrycie tej tematyczno-leksykalnej sekwencji pozwala na stwierdzenie, że między Łukaszowym opisem Dz 15,6-29 a Pawłową relacją Ga 2,7-9, mimo ewidentnych różnic między tymi tekstami, istnieje ścisła (choć

63 W. O. W a 1 k e r, Jr., The Portrayal of Aquila and Priscilla in Acts: The Question of Sources, NTS 54/2008, s. 479-495.

${ }^{64}$ R. S. S c h e 11 e n b e r g, The First Pauline Chronologist? Paul's Itinerary in the Letters and in Acts, JBL 134/2015, s. 193-213. 
wysoce kreatywna) zależność literacka, a nie tylko wykorzystanie ustnych tradycji, ogólnych informacji itp. ${ }^{65}$

Wykorzystanie cytatu z Am 9,11-12 LXX w Dz 15,16-18 stanowi ważny element tej kreatywnej, a jednocześnie ściśle sekwencyjnej przeróbki Ga 2,7-9 w Dz 15,6-29. Do etopeicznej charakteryzacji postaci Jakuba został bowiem przez św. Łukasza wykorzystany starotestamentalny tekst, który w Łukaszowej narracji retorycznie wskazuje na zainteresowania głównie mesjańskie (por. wcześniej 4Q174 [Flor.] frag. 1_2 kol. 1,11-13), a tylko drugorzędnie ewangelizacyjne, judeochrześcijańskiego lidera jerozolimskiej wspólnoty - Jakuba, „brata Pańskiego". Prorocki tekst Am 9,11-12 LXX został nie tylko w kilku miejscach istotnie zmodyfikowany, tak by odpowiadal retoryczno-teologicznym celom św. Łukasza, ale także uzupełniony o wyraźnie obcy fragment (Dz 15,18), który stanowi lingwistyczne echo Pawłowej wzmianki na temat Jakuba jako jednego z jerozolimskich „filarów” (Ga 2,9c). Ponieważ św. Łukasz chciał retorycznie ukazać z jednej strony zgodę, jaką Jakub, wraz z pozostałymi przywódcami jerozolimskiej wspólnoty, wyraził dla ewangelizacyjnej misji Pawła wśród pogan (Ga 2,9a-c), ale z drugiej strony także dystans między Jakubem a Pawłem (por. Ga 1,19), jaki ujawnił się zwłaszcza podczas konfliktu antiocheńskiego (Ga 2,12c. f), dlatego lingwistyczne echo Ga 2,9a-c w Dz 15,18 jest bardzo słabe, rozpoznawalne tylko przy dokładnej intertekstualnej analizie obu tekstów.

To lingwistyczne echo Ga 2,9a-c, sztucznie wprowadzone do cytatu z Am 9,11-12 LXX w Dz 15,16-18, potwierdza jednak, że cytat ten nie został przez św. Łukasza użyty przypadkowo lub też ze względu na jakąś wcześniejszą tradycję. Cytat z Am 9,11-12 LXX został użyty, po dość istotnej modyfikacji, jako element szerszej retorycznej strategii etopeicznej, mającej scharakteryzować postać Jakuba jako człowieka mocno przywiązanego do tekstów starotestamentalnych i do idei mesjańskich, a jednocześnie w pewnym, w istocie dość ograniczonym stopniu, otwartym na Pawłową ideę

${ }^{65}$ Ze względu na różnice między Ga 2 i Dz 15 Łukaszowe wykorzystanie tylko ustnych tradycji sugeruje m in. J. J e r v e 11, Apostelgeschichte, s. 242-243. 
ewangelizacji pogan. Jego deklarowane uznanie dla wyjątkowej łaski, danej Pawłowi, było przy tym według św. Łukasza, jak wskazuje dalekie echo Ga 2,9a-c w Dz 15,18, mocno wątpliwe. Łukaszowy Jakub uznał bowiem nie tyle wyjątkową łaskę, daną osobiście Pawłowi (Ga 2,9a-c), ile ogólne zbawcze działanie Boga, które nie jest niczym wyjątkowym ani nowym, gdyż znane jest od wieków (Dz 15,18). ${ }^{66}$

ks. Bartosz ADAMCZEWSKI

${ }^{66}$ Por. W. R a d 1, Rettung, s. 56. 